\title{
Factors that Affect the Buying Behaviour of the Shippers and Freight Forwarders when Choosing an Ocean Carrier in Sri Lanka
}

\author{
Osanda Chiranthana Ariyadasa ${ }^{1}$, Viraji Waidyasekara ${ }^{2}$ \\ ${ }^{1,2}$ Department of Logistics and Transport, Faculty of Management, Humanities and Social Sciences, CINEC, \\ Millennium Drive, IT Park, Malabe, Sri Lanka \\ ${ }^{1}$ osandachiranthana@gmail.com \\ ${ }^{2}$ virajiwaidyasekara@gmail.com
}

\begin{abstract}
The shipping sector has become the backbone of international trade and globalization. Therefore, the freight transportation selection is of vital importance for the shippers and International Freight Forwarder (IFF). Accordingly, assessment of requirements and trends of freight forwarding while understanding key factors that rule its efficacious movement is a timely want to provide high quality service to societies. This study aims to determine the factors that affect both shippers and IFF's when selecting an ocean carrier preference to the Sri Lanka. Primary data is collected through Questionnaires and 174 questionnaires have been collected. Descriptive analysis has been carried out to check the association between the response variables and explanatory variables. Due to the availability of collinearity between explanatory variables, factor analysis has been carried out. Hypothesis testing has been carried out for ordinal data using Kruskal Wallis test. The factors which affect the buying behaviour of the shippers and international freight forwarders when selecting an ocean carrier with orientation to Sri Lanka can be mainly categorized into facilities, accuracy, frequency and relationship, capacity, reliability and competence, general reputation, service capabilities. service capabilities are dependent on the organization type, Number of employees, Average volume per month and estimated average income per month. General Reputation is dependent on the organization type, Number of employees, Average volume per month and Frequency. Capacity is dependent on the organization type, Firm age and Average volume per month.
\end{abstract}

Keywords - Shippers, Freight Forwarders, Buying Behaviour

\section{INTRODUCTION}

Based on the statistics provided by annual report \& accounts 2010/2011 of Shippers Council, Sri Lanka, there are over 50,000 merchant ships trading internationally, transporting every kind of cargo. The world fleet has registered over 150 nations, and manned by over a million seafarers of virtually every nationality. Considering the Sri Lankan context, statistics suggest that the country has experienced an increase of $22.4 \%$ in imports during the last financial year (2013) compared to that of 2012. The total monetary value of sea exports in 2013 reached USD 10,559 million while the expenditure on sea imports increased by $50.7 \%$ and reached USD 20,269 million in value. Simultaneously, Sri Lanka Ports Authority (SLPA) statistics show that Sri Lanka has experienced $8 \%$ of economic growth during 2010 .
The operating mechanism of ocean carriers vary depending on the types of cargo they transport. Dry bulk carriers, container carriers, roll on roll off (RO-RO) carriers and liquid bulk carriers are the categories of ocean carriers based on cargo type. Among these the container carriers may include selfowned or shipper owned containers as well as self-owned or externally arranged (in other carriers) vessels in order to fulfil the requirements of their customers.

Basic objective is to understand the factors that affect the buying behaviour of both shippers and IFFs when selecting an ocean carrier. The outcome of this study will highlight all important aspects considered by shippers and IFFs, and will in turn directly help the service providers to enhance their service, in terms of both quality and quantity. Study outcome can therefore be used as a direct guideline to improve services provided by ocean carriers at different facets, facilitating their customers with many additional value-added services.

\section{A. Objectives}

Identifying the determinants that affect the buying behaviour of the shippers and international freight forwarders when selecting an ocean carrier

Identifying the factors that are considered as critical by each organization type

\section{METHODOLOGY AND EXPERIMENTAL DESIGN} Online questionnaires were sent to the all registered IFF companies (170) in Sri Lanka. Out of them 40 questionnaires were returned and the response rate was $23.52 \%$. 24 questionnaires were filled physically when visiting them and all together 64 questionnaires were collected from the IFFs. Approximately over 200 questionnaires were sent to the container export companies located in Sri Lanka and 75 questionnaires were returned. The response rate is $37.5 \%$ and 39 completed questionnaires were collected by physically visiting the exporting companies.

Descriptive analysis has been carried out to check the relationship between the response variable and other explanatory variables. Based on the reliable factors hypothesis testing has been carried out for ordinal data using 
Kruskal Wallis test. Factor analysis is the method of data reduction. Correlated variables are grouped together and separated from other variables with low or no correlation Factor analysis could be described as orderly simplification of interrelated measures. Traditionally factor analysis has been used to explore the possible underlying structure of a set of interrelated variables without imposing any preconceived structure on the outcome (Child, 1990). By performing exploratory factor analysis (EFA), the number of constructs and the underlying factor structure are identified. Kruskal Wallis test has been used to $\mathrm{k}$ independent samples which is an extension to the Mann Whitney test.

\section{RESULTS}

\section{A. Descriptive Analysis}

Out of 174 organizations $19 \%$, are organizations that consist of 20 to 39 employees while lowest percentage of $6 \%$ is consist of 60 to 80 numbers of employees. $35 \%$ of organizations have a firm age between 10 to 14 years and only $13 \%$ of companies are older than 20 years. $45 \%$ of organizations (both shippers and IFFs) exporting TEU's "Between 20 to 99". Only 1\% of companies export TEU's over $300.53 \%$ of companies' process daily exports of TEU's while $32 \%$ of companies export their TEU's weekly and $15 \%$ companies export their number of TEU's weekly and monthly. The highest percentage is $28 \%$ and it belongs to companies that have a monthly income of between Rs. 5 million to 10 million.

\section{B. Factor Analysis}

TABLE I. COMMUNALITIES

\begin{tabular}{|c|c|}
\hline Variable & Extraction \\
\hline $\begin{array}{l}\text { On time arrival and departure of an } \\
\text { ocean carrier }\end{array}$ & .415 \\
\hline $\begin{array}{l}\text { Delivering the cargo at promised } \\
\text { transit time without any damage }\end{array}$ & .481 \\
\hline $\begin{array}{l}\text { Maintenance of equipment and } \\
\text { containers in satisfactory condition }\end{array}$ & .750 \\
\hline $\begin{array}{l}\text { Convenience in taking and returning } \\
\text { the containers at the yard }\end{array}$ & .739 \\
\hline Historical operation performance & .713 \\
\hline Reputation of the carrier & .647 \\
\hline Finance stability & .708 \\
\hline Loss and damage record & .516 \\
\hline $\begin{array}{l}\text { Issuing competitive \& accurate price } \\
\text { quotations for inquiries }\end{array}$ & .665 \\
\hline Negotiation of rates & .540 \\
\hline $\begin{array}{l}\text { EDI (Electronic Data Interchange) \& } \\
\text { tracking facility }\end{array}$ & .645 \\
\hline Multimodal service & .633 \\
\hline Geographical coverage & .690 \\
\hline
\end{tabular}

\begin{tabular}{|l|c|}
\hline $\begin{array}{l}\text { Expertise / knowledge of sales } \\
\text { representatives }\end{array}$ & .610 \\
\hline Frequency of sailings & .526 \\
\hline Credit facility for their customers & .680 \\
\hline $\begin{array}{l}\text { Free detention period at destination } \\
\text { port }\end{array}$ & .608 \\
\hline Customer relationship & .488 \\
\hline Informing the status of the cargo & .520 \\
\hline Speed of issuing shipping documents & .534 \\
\hline $\begin{array}{l}\text { Accuracy of shipping documents \& } \\
\text { bills }\end{array}$ & .658 \\
\hline Speed processing of claims & .622 \\
\hline Space availability & .627 \\
\hline Speed operation process & .718 \\
\hline $\begin{array}{l}\text { The competency of emergency } \\
\text { handling }\end{array}$ & \\
\hline
\end{tabular}

Table 1 shows how much variance in the variables has been accounted for by the extracted factors. According to the table 1 Over $75 \%$ of the variance Maintenance of equipment and containers in satisfactory condition is accounted for while $74.6 \%$ of the variance in Space availability is accounted for.

TABLE II. TOTAL VARIANCE EXPLAINED

\begin{tabular}{|c|c|c|c|}
\hline Component & $\begin{array}{c}\text { Cumulative } \\
\%\end{array}$ & Total & $\begin{array}{c}\% \text { of } \\
\text { Variance }\end{array}$ \\
\hline 1 & 20.568 & 2.995 & 11.979 \\
\hline 2 & 30.955 & 2.610 & 10.439 \\
\hline 3 & 37.752 & 1.949 & 7.794 \\
\hline 4 & 43.663 & 1.853 & 7.413 \\
\hline 5 & 48.725 & 1.831 & 7.322 \\
\hline 6 & 53.436 & 1.806 & 7.224 \\
\hline 7 & 57.865 & 1.255 & 5.019 \\
\hline 8 & 61.918 & 1.182 & 4.727 \\
\hline
\end{tabular}

As per the Table 2 all 25 variables are explained in eight factors. The percentages of variances are attributable to each factor and the cumulative variance of the respective factor is equal to the sum of percentage of variance of the respective factor and other previous factor. First factor accounts for $20.568 \%$ of the variance, second to $10.387 \%$, third to $6.797 \%$, fourth to $5.911 \%$, fifth to $5.062 \%$, sixth to $4.711 \%$, seventh to $4.429 \%$ and the eighth to $4.052 \%$. The total variance explained by the factor model is $61.918 \%$.

TABLE III. INTERPRETATION OF THE FACTOR MODEL

\begin{tabular}{|l|r|}
\hline FACTOR 1 - Service Capabilities includes & \\
\hline On Time Arrival and Departure of an Ocean Carrier & .616 \\
\hline Multimodal Service & .452 \\
\hline Free Detention Period at Destination Port & .612 \\
\hline Informing the Status of the Cargo & .620 \\
\hline
\end{tabular}




\begin{tabular}{|l|r|}
\hline Speed Processing of Claims & .750 \\
Speed Operation Process & .564 \\
\hline The Competency of Emergency Handling & .659 \\
\hline FACTOR 2- General Reputation includes & \\
\hline On Time Arrival and Departure of an Ocean Carrier & 0.323 \\
\hline Historical Operation Performance & 0.723 \\
\hline Reputation of the Carrier & 0.780 \\
\hline Finance Stability & 0.791 \\
\hline Loss and Damage Record & 0.553 \\
\hline FACTOR 3- Container \& Equipment includes & \\
\hline Maintenance of Equipment and Containers in & .814 \\
\hline Satisfactory Condition & .826 \\
\hline Convenience in Taking and Returning the \\
Containers at the Yard \\
\hline FACTOR 4 - Facilities includes \\
\hline Geographical Coverage \\
\hline Credit Facility for Their Customers \\
\hline FACTOR 5 - Frequency \& Relationship includes \\
\hline Negotiation of Rates \\
\hline Frequency of Sailings \\
\hline Customer Relationship \\
\hline FACTOR 6 - Reliability \& Competence includes \\
\hline Delivering the Cargo at Promised Transit Time \\
\hline without Any Damage \\
\hline Issuing Competitive \& Accurate Price Quotations \\
for Inquiries \\
\hline Expertise / Knowledge of Sales Representatives \\
\hline Speed of Issuing Shipping Documents \\
\hline \\
\hline FACTOR 7 - Accuracy includes \\
\hline .734 \\
\hline .739 \\
\hline
\end{tabular}

\section{Hypothesis Testing for Factors}

The hypothesis below has been checked by performing the Kruskal Wallis test;

Ho: Factor is independent from the ith variable

H1: Factor is dependent on the ith variable

$i^{\text {th }}$ Variable - Organisation type, No. of employees, Firm age, Average volume per month, Frequency, Approximate average income per month

TABLE IV. HyPothesis TESTING TEST RESULTS OF ORGANISATION TyPE

\begin{tabular}{|l|l|}
\hline & Asymp. Sig. \\
\hline Service Capabilities & .000 \\
\hline General Reputation & .031 \\
\hline Container \& Equipment & .055 \\
\hline Facilities & .930 \\
\hline Frequency \& Relationship & .432 \\
\hline Reliability \& Competence & .175 \\
\hline Accuracy & .528 \\
\hline Capacity & .025 \\
\hline
\end{tabular}

There is significant association between Organization Type with the General Reputation and Capacity as significant values are below $5 \%$.

TABLE V. Hypothesis Testing Test Results of No. of EMPloyeEs

\begin{tabular}{|l|l|}
\hline & Asymp. Sig. \\
\hline Service Capabilities & .000 \\
\hline General Reputation & .005 \\
\hline Container \& Equipment & .076 \\
\hline Facilities & .101 \\
\hline Frequency \& Relationship & .768 \\
\hline Reliability \& Competence & .080 \\
\hline Accuracy & .694 \\
\hline Capacity & .813 \\
\hline
\end{tabular}

There is significant association between Organization Type with the Service Capabilities and General Reputation as significant values are below 5\%.

TABLE VI. Hypothesis TESTING TEST RESUlts of FIRM AgE

\begin{tabular}{|l|l|}
\hline & Asymp. Sig. \\
\hline Service Capabilities & .120 \\
\hline General Reputation & .724 \\
\hline Container \& Equipment & .294 \\
\hline Facilities & .650 \\
\hline Frequency \& Relationship & .593 \\
\hline Reliability \& Competence & .231 \\
\hline Accuracy & .788 \\
\hline Capacity & .048 \\
\hline
\end{tabular}

There is significant association between Organization Type with the Capacity as significant values are below $5 \%$.

TABLE VII. Hypothesis Testing Test Results of Average Volume Per MONTH

\begin{tabular}{|l|l|}
\hline & Asymp. Sig. \\
\hline Service Capabilities & .001 \\
\hline General Reputation & .043 \\
\hline Container \& Equipment & .100 \\
\hline Facilities & .960 \\
\hline Frequency \& Relationship & .714 \\
\hline Reliability \& Competence & .482 \\
\hline Accuracy & .084 \\
\hline Capacity & .432 \\
\hline
\end{tabular}

There is significant association between Organization Type with the Service Capabilities, General Reputation and Capacity as significant values are below $5 \%$. 
TABLE VIII. HyPothesis TESTING TEST RESUlts OF FREQUENCY

\begin{tabular}{|l|l|}
\hline & Asymp. Sig. \\
\hline Service Capabilities & .693 \\
\hline General Reputation & .027 \\
\hline Container \& Equipment & .138 \\
\hline Facilities & .291 \\
\hline Frequency \& Relationship & .531 \\
\hline Reliability \& Competence & .401 \\
\hline Accuracy & .459 \\
\hline Capacity & .250 \\
\hline
\end{tabular}

There is significant association between Organization Type with the General Reputation as significant values are below $5 \%$.

TABLE IX. Hypothesis Testing Test Results of ApProXimate Average INCOME PER MONTH

\begin{tabular}{|l|l|}
\hline & Asymp. Sig. \\
\hline Service Capabilities & .020 \\
\hline General Reputation & .086 \\
\hline Container \& Equipment & .089 \\
\hline Facilities & .918 \\
\hline Frequency \& Relationship & .752 \\
\hline Reliability \& Competence & .798 \\
\hline Accuracy & .416 \\
\hline Capacity & .136 \\
\hline
\end{tabular}

There is significant association between Organization Type with the Service capabilities as significant values are below $5 \%$.

\section{CONCLUSION}

Factors that affect the carrier selection process (with regards to IFFs and Shippers) were identified as Facilities, Accuracy, Frequency and Relationship, Capacity, Reliability and Competence, Container and Equipments, General Reputation and Service Capabilities. Result generated in hypothesis testing led in arriving at following conclusions:

Identified the followings which shows the association between Organization infrastructure and the carrier selection criteria

1. Service capabilities (factor 1 ) is dependent on the organization type, Number of employees, Average volume (TEUs) per month and approximate average income per month.

2. General Reputation (factor 2) is dependent on the organization type, Number of employees, Average volume (TEUs) per month and Frequency.

3. Capacity (factor 8) is dependent on the organization type, Firm age and Average volume (TEUs) per month.

\section{REFERENCES}

[1] (2011). Annual Report \& Accounts 2010/2011. Colombo: Sri Lanka Shippers' Council. Business Dictionary.Com. (N.D.). Retrieved August 2014,

[2] Child, D.(1990).The essential of factor analysis, second edition. London: Cassel Educational Limted. Forwarder: : :/M.Businessdictionary.Com/Definition/FreightForwarder.Html 